http://dx.doi.org/10.5935/1981-2965.20120004

Artigo Cientifico

www.higieneanimal.ufc.br/

\title{
Chemical composition and lipids classes of the freshwater fish tilapia do Nilo, Oreochomis niloticus
}

Composição química e classes de lipídios em peixe de água doce tilapia do Nilo, Oreochomis niloticus

\author{
Ronaldo de Oliveira Sales ${ }^{1 *}$, Everardo Lima Maia ${ }^{2}$ \\ ${ }^{1}$ Ceará Federal University - DZ / CCA / UFC. E-mail: ronaldo.sales@ufc.br \\ ${ }^{2}$ Ceará Federal University - DE / CCA / UF.E-mail: maiadep@uol.com.br \\ * To whom correspondence should be sent
}

\begin{abstract}
The purpose of this work is to quantify lipid classes founded in fillets of Tilapia do Nilo, Oreochomis niloticus. The total lipids (TL) were fractionated by open column chromatography in neutral lipids (NL), glyceroglycolipids (GL) and glycerophospholipid (PL). Five lots of samples, each one containing four specimens, were obtained from retail stores in Fortaleza (Ceará State - Brazil) in sep, oct, nov and dec of 2011. The TL was averaged in $3.8 \%$ of muscle, on wet mass basis. The dominant lipid class was NL averaging at $74.5 \%$ in relation to the TL or $2.9 \mathrm{~g} / 100 \mathrm{~g}$ of fillet. The GL and PL contributed on average with $1.5 \%(61 \mathrm{mg} / 100 \mathrm{~g}$ of fillet) and $23.1 \%(885 \mathrm{mg} / 100 \mathrm{~g}$ of fillet $)$, respectively. The approximate composition had average of $76.0 \%$ moisture, $19.3 \%$ total protein, and $2.0 \%$ ash.
\end{abstract}

Keywords: freshwater fish, neutral lipids, glycolipids, phospholipids, composition.

Resumo: O presente trabalho teve como objetivo obter dados quantitativos sobre as classes de lipídios encontrados nos files de tilapia do Nilo, Oreochomis niloticus. Os lipídios totais (LT) foram fracionados em classes de lipídios neutros (LN), gliceroglicolipídios (GL) e 
glicerofosfolipídios (PL) através de cromatografia em coluna aberta de sílica gel 60 (70-230 mesh). As análises foram realizadas em cinco lotes de amostras contendo cada uma quatro exemplares, adquiridos em feiras livres de Fortaleza-CE, nos meses de set, out, nov e dez de 2011. Os LT representaram em média 3,8\% em relação ao peso fresco da amostra. A classe lipídica dominante foi de LN com média de 74,5\% dos LT ou 2,9g/100g de filé. Os GL e PL contribuíram em média com 1,5\% (61mg/100g de filé) e $23,1 \%$ ( $885 \mathrm{mg} / 100 \mathrm{~g}$ de filé), respectivamente. A composição química centesimal apresentou média de 76,0\% de umidade, 19,3\% de proteína total e 2,0\% de cinza.

Palavras-chave: silagem ácida de peixe, lipídios neutros, glicolipídios, fosfolipídios, composição.

\footnotetext{
* To whom correspondence should be sent Recebido em 20.03.2012. Aceito em 28.05.2012
}

\section{Introduction}

Among the fish species used in aquaculture, tilapias, especially the genus Oreochromis, are some of the most promising in tropical or subtropical climate countries (CAMPOS-RAMOS, 2003; DESPREZ et al., 2003).

The species of the genus Oreochromis are of commercial importance in all regions of Brazil, especially in the Brazilian Northeast, due to its ability to adapt to different aquatic environments, easiness of artificial fertilization, high prolificacy and precocity, diet, and especially by its wide acceptance by the population (SOUZA et al., 2001, MENEZES, 2006).

The knowledge of the chemical composition, in the value of cholesterol and the fatty acid profile of tilapia fillet, is necessary in order to stimulate its consumption, making possible the competition with other widely used protein sources such as beef, pork and poultry. 
As it is a species highly consumed by the Brazilian population, the cichlid fish have been investigated as to their approximate chemical composition (BRUSCHI, 2001; KUBITZA， 2000), while MAIA (1990) investigated the seasonal variation of the $O$. niloticus fat content, and (MEURER et al., 2002 and FERREIRA, 2007) analyzed the São Paulo curimbatá amino acid and/or fatty acids composition, as well as the contents of lipid classes and their respective fatty acid compositions.

It is known that the chemical constituents in fish vary between different species and even between individuals of the same species, depending on the time and place of capture, habitat, sex, age, among other factors (JACQUOT, 1961; STANSBY, 1962), therefore, the objective of this study is to obtain information about chemical composition and contents of neutral lipid classes, glycolipids and phospholipids in the tilapia do Nilo (Oreochomis niloticus) of the State of Ceará.

\section{Material and methods}

The samples consisted of specimens of tilapia do Nilo, Oreochomis niloticus, without distinction of sex or size. Four samples, each one containing three specimens, from dams, were obtained from retail stores in Fortaleza-Ceará, in the months of Sep, Oct, Nov and Dec of 2011. The average weight of the respective samples were $340 \mathrm{~g}(300-400 \mathrm{~g})$, 400g (380$410 \mathrm{~g}), 400 \mathrm{~g}(320-520 \mathrm{~g})$ and $300 \mathrm{~g}(230-$ $380 \mathrm{~g}$ ), resulting in four skinless fillets, which after been cut into small pieces, were gathered and homogenized with the aid of MASTER WALITA multiprocessor. This homogeneous mass, also named as edible portion, containing small pieces of intramuscular fish bones, was used to determine the centesimal chemical composition and the analysis of lipid 
classes.

\section{Centesimal Chemical Composition}

The water and ash contents were determined in triplicate, according to the procedure described by AOAC (2000), while the protein content was determined, in triplicate, by the semi-micro Kjeldahl method AOAC (2000), using the factor 6.25 for the conversion of total nitrogen into gross protein.

Fifty grams (50g) of the homogeneous mass was used for the cold extraction of total lipids (TL) by the method of BLIGH \& DYER (1959), taking into account the proportions between tissue water and extraction solvents: chloroform $\left(\mathrm{CHCl}_{3}\right)$ and methanol. The purified chloroform extract was filtered through filter paper containing a little of anhydrous $\mathrm{Na}_{2} \mathrm{SO}_{4}$ to absorb the moisture, washed with $\mathrm{CHCl}_{3}$, completing the known volume with $\mathrm{CHCl}_{3}$. Then, three $10 \mathrm{~mL}$ aliquots were transferred from this extract to an aluminum pre-tared capsule, and then placed in an incubator at $105^{\circ} \mathrm{C}$ for about
30 minutes to evaporate the solvent. After cooling in a dehydrator containing silica gel and evacuated the atmospheric air with a tube of water, the capsule was weighed on an analytical scale, obtaining the content of TL expressed regarding the weight of the moisture sample. The remainder of the chloroform extract was concentrated in a rotary vacuum evaporator at a temperature of $40^{\circ} \mathrm{C}$, until considerable reduction of the solvent, and then it was transferred to an amber bottle and stored in the "freezer" at $-30^{\circ} \mathrm{C}$ for later use in the separation of lipid classes.

\section{Separation of Lipid Classes}

The procedure described by Johnston et al. (1983) was used for the separation of TL in lipid classes, using silica gel 60 (70-230 mesh) as adsorbent and the solvents chloroform, acetone and methanol for elution, respectively, of neutral lipids (NL), glyceroglycolipids or glycolipids (GL) and glycerophospholipid or phospholipids (PL). After evaporation of solvents through a rotary vacuum 
evaporator at $40^{\circ} \mathrm{C}$, the fractions were transferred to pre-tared amber bottles, with the smallest possible volume of $\mathrm{CHCl}_{3}$, which was evaporated under vacuum using double boiler and nitrogen, and then placed in a desiccator and weighed until reaching a constant weight (accuracy of $\pm 10 \mathrm{mg}$ ) on an analytical scale. The percentages of lipid classes were calculated based on the weight of the TL. For comparison with literature results, contents of lipid classes are also expressed as a percentage regarding the weight of the sample (edible portion).

\section{Results and discussion}

\section{Centesimal Chemical Composition}

The results of the centesimal chemical composition of the tilapia do Nilo edible portion are described in Table 1 The mean values of lipids and proteins in most samples enable to classify this species in category A where the fish have low fat content $(<5 \%)$ and high protein content (15-20\%) (IZQUIERDO, 2000). The exception occurred with the March sample that had $5.8 \%$ lipids, being on the threshold of the category B (5 to $15 \%$ of TL). The average content of $19.3 \pm 0.9 \%$ protein, which had a small variation coefficient $(\mathrm{CV}=4.2 \%)$, lies very close to those reported for other species of the genus Oreochromis, varying between 18.0 and 20.5\% (EL-SAYED, 2002; IZQUIERDO, 2000). For Junk (1985), the protein content of tilapia do Nilo in the Amazon River remained fairly stable at around $20 \%$ for much of the year, but during the early period of increased volume of river water (from February to April), the protein content gradually decreased, reaching the minimum value of $17 \%$ in March, to thereafter, increase again, which in April had again reached an average of $20 \%$.

Coincidentally, the lowest protein value $(19.1 \%)$ of tilapia in the Ceará pond has also been found in March, the rainy season in the Brazilian Northeast. However, the protein average reported by (Minozzo, 2005) (19,4\%) was obtained with samples collected in the months of 
January, May and July in the rivers of the

State of Paraná. Lichetenstei et al. (2000)

found contents varying from 18.47 to

19.33\%. According to Kirk \& Sawyer

(1981) when the Kjeldhal method is

applied, the total centesimal composition

can exceed $100 \%$, due to the multiplication

of nitrogen by 6.25 , which was observed in

this study (Table 1).

Thus, it appears that the habitat has

little influence on the protein content of the fish of the genus Oreochomis, whereas the small variation observed in the protein, might be due to seasonal variation of food. It is known that these species have a preference for elements of the phytoplankton, but can consume small larvae, insects and worms and then feed on silt or mud from the bottom of ponds containing algae (especially diatoms), plant debris and sand particles (Silva et al., 2002), probably present in greater quantity and diversity during the rainy season.

Regarding the total lipids content (TL), the average of $3.8 \pm 1.5 \%$ is between the values of 0.5 and $4.0 \%$ reported for Prochilodus scrofa, Prochilodus cearensis and Prochilodus nigricans (MAIA et al., 1999). Higher values were observed for $P$. scrofa which averaged $6.0 \%$ (MAIA et al., 1995), while the Prochilodus cearensis, without distinction of sex and size, averaged 11.2\% (OLIVEIRA, 1999). This same species analyzed in the years 2006 and 2007 showed, respectively, an average of $12.6 \%$ and $9.2 \%$ for males and $13.3 \%$ and $9.2 \%$ for females (CAULA et al., 2008). Perhaps the specimens sizes may be contributing to the wide variation observed among species of the genus Prochilodus cearensis, Plagioscion squamosissimus and Hoplias malabaricus as, according to Oliveira (1999), it was observed a significant positive correlation between length and fat content, in both Prochilodus cearensis males and females.

The inverse relationship between moisture and lipid contents observed in several fish (Oliveira, 1999; Maia, 1995; Maia et al., 1999; Urbinati, 2004) can also 
be seen between the samples of tilapia

(Table 1). However, the sample of

September, compared to the samples of

November and Dezember, but not in

comparison with the sample of October, deviated from this behavior. The sum of the moisture and lipids contents, averaged $80 \%$, equal to the value of Izquierdo (2000), and very close to $80.7 \%$ Oliveira (1999) and 81\% (VILA NOVA, 2005).

Table 1. Data on the percentage chemical composition of tilapia do Nilo, Oreochomis niloticus.

\begin{tabular}{ccccc}
\hline Sample & & \multicolumn{2}{c}{ Chemical composition (\%) } & \\
& Moisture & Protein & Lipids & Ash \\
\hline September & 75.1 & 19.5 & 4.2 & 2.1 \\
October & 75.8 & 19.2 & 4.6 & 2.3 \\
November & 74.9 & 19.6 & 3.9 & 1.8 \\
December & 78.5 & 19.1 & 3.5 & 1.9 \\
Average & $76.0 \pm 1.6$ & $19.3 \pm 0.9$ & $4.9 \pm 1.6$ & $2.0 \pm 0.4$ \\
\hline
\end{tabular}

The average content of $2.0 \pm 0.4 \%$ for ash is within the normal value reported for freshwater fish (Santos et al., 2001) and marine (Melo, 2003), but higher average content between 3.0 and $4.2 \%$ have been reported for freshwater fish (Caula, 2008) and from 2.5 to $3.2 \%$ for marine fish (ÇELIK et al., 2005).

\section{Lipid Classes Content}

Table 2 shows the contents of the classes of neutral lipids (NL), glycolipids (GL) and phospholipids (PL) separated from total lipids (TL) of fillets of tilapia do Nilo Oreochomis niloticus. The NL was always the majority class, contributing on average with $74.5 \%$ of TL. 
The averages of GL and PL were $1.5 \%$ and $23.1 \%$, respectively. Losses occurred during the chromatographic separation process, as the average recovery of the 4 samples was $83.1 \%$. It is known that PL are the constituents more susceptible to enzymatic hydrolysis and autoxidation during the handling (Oetterer et al., 2004) or storage of fish on ice (Pérez et al., 2001) or frozen.

Moreover, according to LAMBERTSEN (1972), the recovery reduction is associated with retention in the column of products more acid, free fatty acid and/or some products derived from the oxidation of lipids. For a more realistic comparison of the results obtained in this study with those from the literature, which had recoveries of at least $98 \%$ (ERIC et al., 2005), the data presented in Table 2 were corrected to $100 \%$ of recovery.

In work with curimbatá, $P$. scrofa captured in the State of Alagoas, Menezes (2006) found averages of $88.1 \%$ of NL and $11.8 \%$ of PL, but did not detect glycolipids. Likewise, it was verified the absence of GL in tambaqui, Colossoma macropomum (Araújo-Lima \& Goulding, 1997) and in pacu, Piaractus mesopotamicus (Ramos Filho, et al., 2008), which showed, respectively, $90.7 \%$ of NL $+8.7 \%$ of PL and $94.0 \%$ of $\mathrm{NL}+5.0 \%$ of PL.

There are controversies about the presence of glycolipids in the edible muscle tissue of fish. In 17 different species of fish from Ceará, Oliveira (1999) did not record the occurrence of glycolipids.

This lipid class was not detected in "ayu" neither, Plecoglossus altivelis cultured or natural, or in white and dark meat of "white sucker", Catostomus commersoni, nor in five species of freshwater and marine fish and 3 species of "shellfish" (NAKAGAWA, 2004).

On the other hand, Wilson et al. (2006) reported the presence of glycolipids in quantities of $1.9 \%$ (equivalent to $22.8 \mathrm{mg} / 100 \mathrm{~g}$ of sample) in muscle lipid 
extract of shrimp, Penaeus aztecus, while

Banerjee et al. (1997) found in "milkfish",

Chanos chanosan average of $2.4 \%$ of GL and Bruschi (2001) reported very high levels of the order of $26.4 \%$ of GL in the body flesh fish from the mangrove Boleophthalmus boddaerti from India.

Table 2. Content of lipid fractions in tilapia do Nilo, Oreochomis niloticus.

\begin{tabular}{lcccccc}
\hline Samples & \multicolumn{5}{c}{ Lipid classes content } \\
& \multicolumn{7}{c}{$\%(\mathrm{~g} / 100 \mathrm{~g} \mathrm{TL})$} & $\mathrm{g} / 100 \mathrm{~g}$ sample \\
& $\mathrm{NL}$ & $\mathrm{GL}$ & $\mathrm{PL}$ & $\mathrm{NL}$ & $\mathrm{GL}$ & $\mathrm{PL}$ \\
\hline September & 72.7 & 3.3 & 21.9 & 3.79 & 0.17 & 1.17 \\
October & 80.6 & 0.9 & 17.4 & 2.85 & 0.05 & 0.62 \\
November & 76.4 & 1.4 & 23.5 & 3.04 & 0.07 & 0.91 \\
December & 68.4 & 0.6 & 29.8 & 1.75 & 0.02 & 0.74 \\
Average & $74.5 \pm 5.2$ & $1.5 \pm 1.4$ & $23.1 \pm 5.4$ & $2.85 \pm 0.9$ & $0.07 \pm 0.07$ & $0.86 \pm 0.24$ \\
\hline
\end{tabular}

Abbreviation: NL = neutral lipids; GL = glyceroglycolipids; PL = glycerophospholipid.

\section{Conclusion}

Considering the results of the research, it is concluded that: The tilapia nilotica is a fish that has low fat content and high protein content;

Comparison of tilapia protein contents with those reported in the literature for other species of the genus Oreochomis suggests that the habitat does not affect the results of the protein;
It was observed an inverse relationship between total lipids and moisture contents, with the sum of these constituents being on average $80 \%$;

Among the lipid components, the majority class was composed of neutral lipids that showed concentration approximately 3 times higher than that of phospholipids. 


\section{References}

ARAÚJO-LIMA， C.R.M.; GOULDING,

M. So fruitful fish: ecology, conservation, and aquaculture of the Amazon's tambaqui. New York: Columbia University Press, 1997. 157p.

\section{ASSOCIATION OF OFFICIAL} ANALYTICAL CHEMISTS (AOAC). Horwitz, Washington. Oficial Methods of Analysis of Association of Official Analytical Chemists. 17 ed. Arlington: AOAC Inc., 2000.

BANERJEE, D. et al. Lipids and Fatty Acids of Air Breathing Fish Boleophthalmus boddaerti. Food

Chemistry, v. 60, n. 3, p. 303-309, 1997.

BLIGH, E.G.; DYER, W.J. A Rapid Method of Total Lipid Extraction and Purification. Canadian Journal of Biochemistry and Physiology, v. 37, n. 8, p. 911-917, 1959.
BRUSCHI, F.L.F. Rendimento, composição centesimal e perfil de ácidos graxos de pescados e seus resíduos monografia [Graduação em Oceanografia]. Itajaí, Santa Catarina. Centro de Ciências Tecnológicas da Terra e do Mar, Universidade do Vale do Itajaí. 2001. $134 p$.

CAMPOS-RAMOS, R. et al. An investigation of sex determination in the Mozambique tilapia, Oreochromis mossambicus, using synaptonemal complex analysis, fish, sex reversal and gynogenesis. Aquaculture, (221):125-40, 2003.

CAULA, F.C.B. et al. Teor de colesterol e composição centesimal de algumas espécies de peixes do estado do Ceará. Ciência e Tecnologia de Alimentos, v. 28, n. 4, p. 960-964, 2008. 
ÇELIK, M. et al. Comparison of the Proximate Compositions and Fatty Acid Profiles of Zander (Sander lucioperca) From Two Different Regions and Climatic Conditions. Food Chemistry, Champaign, v.92, n. 4, p. 637-641, 2005.

DESPREZ, D. et al. Production of a high percentage of male offspring with a natural androgen, 11bhydroxyandrostenedione (11bOHA4), in Florida red tilapia. Aquaculture, v. 216, p. 55-65. 2003.

EL-SAYED, A. Effects of stocking density and feeding levels on growth and feed efficiency of nile tilapia (Oreochromis niloticus L.) fry. Aquaculture Research, v. 33, 621-6. 2002.

ERIC J. et al. Characterization of lipids in complex samples using comprehensive two-dimensional gas chromatography with time-of-flight mass spectrometry. Journal of chromatography, 1086(1-2):2-11. 2005.

FERREIRA, M.W. et al. Efeito dos métodos de cocção sobre a composição química e perfil lipídico de filés de tilápia do Nilo (Oreochromis niloticus Linnaeus, 1757). Ciência e Agrotecnologia, v. 31, n. 3, p. 798-803, 2007.

KIRK, R.S; SAWYER. R. Pearson's composition and analysis of foods. 9th, ed. Harlow Essex, Longman, 504-18, 1981

KUBITZA, F. Tilápia: tecnologia e planejamento na produção comercial. Jundiaí: Acqua \& Imagem, 2000. 289p.

IZQUIERDO, P.C. et al. Análisis proximal, perfil de ácidos grasos, aminoácidos esenciales y contenido de minerals en doce especies de pescado de importancia commercial en Venezuela. Archivos Latino Americanos de Nutricion, 50, 187-194, 2000.

JACQUOT, R. Organic Constituents of Fish and Other Aquatic Foods. In: BORGSTROM, G. (Ed.), Fish Food. London: Academic Press, v.1, p. 145-210, 1961.

JOHNSTON, J.J. et al. Characterization of Shrimp Lipids. Journal of Food Science, v. 48, n. 1, p. 33-35, 1983. 
JUNK, W.J. Temporary Fat Storage an Adaptation of Some Fish Species to the Waterlevel Fluctuation and Related Environmental Changes of the Amazon River. Amazoniana, v. IX, n. 3, p. 315$351,1985$.

LAMBERTSEN, G. Lipids in Fish Fillet and Liver - A comparison of fatty acid compositions.

Fiskeridirektoratets

Skrifter Serie Teknologiske

Undersokelser, v. 15, n. 6, p. 3-15, 1972.

LICHETENSTEIN, A.H. et al. Dietary guidelines: revision 2000: a statement for healthcare professionals from the nutrition committee of the American heart Association. Circulation, (102/18): 228499, 2000

MAIA, E.L. Otimização da Metodologia para a Caracterização de Constituintes Lipídicos e Determinação da Composição em Ácidos Graxos e Aminoácidos de Peixes de Água Doce. Campinas: 242p. (Tese de Doutorado). FEA/UNICAMP, 1990.
MAIA, E.L. et al. Fatty Acid Composition of the Total, Neutral and Phospholipids of Pond-Raised Brazilian Piaractus mesopotamicus. International_Journal_of Food Science and Technology, v. 30, p. 591-597, 1995.

MAIA, E.L. et al. Composição química e classes de lipídeos em peixes de água doce curimatã comum (Prochilodus cearensis). Ciência e Tecnologia de Alimentos, v.19, n.3, p.433-437, 1999.

MELO, J.F.B. et al. Efeito da alimentação na composição química da carcaça do jundiá Rhamdia quelen. Revista Biodiversidade Pampeana, v.1, n.1, p.1223, 2003.

MEURER, F. et al. Lipídeos na alimentação de alevinos revertidos de tilápia do Nilo (Oreochromis niloticus L.). Revista Brasileira de Zootecnia, v. 31, n.2, p. 566-73, 2002.

MINOZZO, M.G. Elaboração de patê cremoso a partir de filé de tilápia do Nilo (Oreochromis niloticus) e sua caracterização físico-química 
microbiológica e sensorial. [Dissertação de Mestrado]. Curitiba, Paraná: Universidade Federal do Paraná, 2005. 127pp.

MENEZES, M.E.S. Valor nutricional de espécies de peixes (água salgada e estuário) do estado de Alagoas. (Dissertação de Mestrado). Maceió, Alagoas: Universidade Federal de Alagoas, 2006. 113p.

NAKAGAWA, H.M. et al. Utilization of $\boldsymbol{\alpha}$-starch in ayu, Plecoglossus altivelis, relating to growth and body composition. Journal of Applied Ichthyology, v.20, n.5, p. $389-394,2004$.

OETTERER, M.; SIQUEIRA, AA.Z.C.; GRYSCHEK, S.B. Tecnologias emergentes para processamento do pescado produzido em piscicultura. In: CYRINO, J. E. P.; URBINATI, E.C.; FRACALOSSI, D.M.; CASTAGNOLLI, N. (Ed.). Tópicos Especiais em Piscicultura de Água Doce Tropical Intensiva. São Paulo: TecArt, 2004. Cap. 15, p. 481-500.
OLIVEIRA, S.L.C.L. Estudo dos Constituintes Lipídicos em Peixes do Ceará. Fortaleza: DEP/UFC, 1999. 118p. (Dissertação de Mestrado).

PEREZ, J.A.A. et al. Relatório da reunião técnica de ordenamento da pesca de arrasto nas regiões sudeste e sul do Brasil. Notas Técnicas da FACIMAR, 5:1-34, 2001.

RAMOS FILHO, M.M, et al. Perfil lipídico de quatro espécies de peixes da região pantaneira de Mato Grosso do Sul.

Ciência Tecnologia de Alimentos, 2008; 28(2): 361-5.

SANTOS, A.B. et al. Composição química e rendimento do filé da traíra (Hoplias malabaricus) Revista da Faculdade de Zootecnia, Veterinária e Agronomia, v.7/8, n.1, p.33-39, 2001.

SILVA, P.C. et al. Desempenho produtivo da tilápia do Nilo (Oreochromis niloticus L.) em diferentes densidades e trocas de água em "raceway".Acta Scientiarum, (24/4):935-41, 2002. 
SOUZA, M.L.R.; MARANHÃO, T.C.F.

Rendimento de carcaça, filé e subprodutos

da filetagem da tilápia do Nilo,

Oreochromis niloticus (L), em função do

peso corporal. Acta Scientiarum,

Maringá, v.23, n.4, p.897-901, 2001.

STANSBY, M. E. Proximate Composition

of Fish. In: HEEN, E.; KREUZER, R.

(Eds.), Fish in Nutrition. London: Fishing

News, p. 55-60, 1962.
VILA NOVA, C.M.V.M. et al. Composição química, teor de colesterol e caracterização dos lipídios totais de tilápia (Oreochromis niloticus) e pargo (Lutjanus purpureus). Ciência Tecnologia de Alimentos, (25/3): 430-436. 2005.

WILSON M.F. et al. Composição centesimal e perfil de ácidos graxos do camarão-d'água-doce. Revista Brasileira de Zootecnia. vol. 35 n.4, 2008. 